\title{
ISKANJE HOMERJEVE ITAKE Bittlestone, R., Diggle, J., Underhill, J.: Odysseus unbound. The search for Homer's Ithaca. Cambridge University Press. Cambridge 2005.
}

Tudi če zgodovine $\mathrm{v}$ osnovni in srednji šoli niste uvrščali med svoje priljubljene predmete, ste morda z zanimanjem prebirali o dogodivččinah premetenega in praktično neuničljivega Odiseja z Itake. številnih prevodov in znanstvenih razprav o literarnih, mitskih, zgodovinskih razsežnostih in, nenazadnje, o Homerjevem avtorstvu

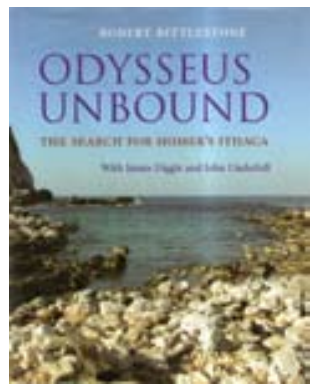
je bila zgodba ali njena simbolika vir navdiha za številne umetniške stvaritve.

Obravnavano delo izrazito odstopa od omenjenih. Dokazati namreč poskuša, da se današnje poimenovanje Itake, $v$ Odiseji in Iliadi omenjenega Odisejevega kraljestva, nanaša na napačen otok. Dvom o pravilnosti lokacije Homerjeve Itake ni nov, avtor govori o '3200 let stari detektivski zgodbi'. Za razliko od vsaj delno prepričljivega ujemanja Schliemannovih izkopanin Troje s Homerjevimi opisi so bila v tem pogledu arheološka izkopavanja na sedanji Itaki neuspešna. Bittlestone $\mathrm{v}$ tem delu dokazuje, da je bila Homerjeva Itaka pravzaprav zahodni del otoka Kefalenija (tudi Kefalonija, orig. Kefallinía; Kladnik 2006, priloga str. 116). To domnevo dokazuje s pomočjo satelitskih posnetkov, ekspertnimi mnenji geologov ter podrobnimi geografsko-zgodovinskimi analizami antičnih besedil. Glavni geološki oziroma geomorfni proces, ki naj bi Kefalenijo združil z nekdanjo domnevno Itako, je bila izredno živahna potresna zgodovina tega območja, ki naj bi sprožila dviganje otoka ter velike zemeljske plazove in podore, ti pa naj bi prispevali k debelemu zasutju nekdanjega domnevnega preliva med otokoma.

Ne glede na pravilnost Bittlestonovih trditev in domnev je sledenje njegovim razmišljanjem, zapisanim v obravnavano knjigo, miselna pustolovščina za arheologa, geologa in geografa. Avtor se je očitno zavedal svoje preozke znanstvene, zlasti geološke podkovanosti, zato je v svoje delo vpletel številne strokovnjake, dva od njih (jezikoslovca in geologa) je navedel tudi kot soavtorja knjige. Vsi vpleteni niso popolnoma soglasni $v$ razlagah analiziranih informacij in tako vrsta vprašanj iz knjige ostaja odprtih. Bolj kot s trdnostjo spoznanj torej privlači z drznostjo razmišljanja in razlag, geografe pa tudi z iznajdljivim, čeprav preprostim prepletanjem daljinsko zaznanih podatkov, simulacije geoloških in geomorfnih procesov ter antičnih zgodb.

Marko Krevs

\section{Literatura}

Kladnik, D. 2006: Tuja zemljepisna imena v slovenskem jeziku: razvojni vidiki in problematika njihove rabe. Doktorska disertacija. Oddelek za geografijo, Filozofska fakulteta Univerze v Ljubljani. Ljubljana. 